\title{
Cancer care in times of conflict: cross border care in Pakistan of patients from Afghanistan
}

\author{
Muhammed Aasim Yusuf ${ }^{1,}$, Shoaib Fahad Hussainn,, ${ }^{2,}$ Faisal Sultan ${ }^{1}$, Farhana Badar ${ }^{1}$ and Richard Sullivan ${ }^{2}$ \\ ${ }^{1}$ Shaukat Khanum Memorial Cancer Hospital and Research Centre, Lahore, Pakistan \\ ${ }^{2}$ Conflict and Health Research Group, Institute of Cancer Policy, King's College London, London, United Kingdom \\ *Joint First Authors.
}

\begin{abstract}
Armed conflict in Afghanistan has continued for close to 40 years and has devastated its health infrastructure. The lack of a cancer care infrastructure has meant that many Afghans seek cancer care in neighbouring countries, like Pakistan. There remains a significant lack of empirical data on the new therapeutic geographies of cancer in contemporary conflicts.
\end{abstract}

This retrospective single centre study explores the therapeutic and clinical geographies of Afghan cancer patients who were treated at the Shaukat Khanum Memorial Cancer Hospital and Research Centre (SKMCH\&RC) in Lahore, Pakistan over a 22-year-period (1995 to 2017) covering major periods of conflict and relative peace.

Data was available for 3,489 Afghan patients who received treatment at SKMCH\&RC. The mean age at presentation was 42.7 years, and $60 \%$ were men. $30.2 \%$ came from Kabul and Nangarhar districts of Afghanistan, which have relatively short travel times to Pakistan, but patients from all parts of Afghanistan migrated to SKMCH\&RC for treatment. Overall, $34.1 \%$ were diagnosed with upper gastrointestinal malignancies and $55.7 \%$ presented with late stage III/IV cancer. A wide range of treatments were provided, with $25.4 \%$ of patients receiving a combination of chemotherapy and radiation treatment. $52.7 \%$ of all patients were lost to follow-up. Outcomes were more favourable for children with cancer, $42 \%$ of whom had a complete response to therapy.

Complex migration patterns, mixed political economies (refugees, forced and unforced migrants) and models of care that must be adapted to the realities of the patients rather than notional international standards all reflect the new therapeutic geographies that long-term conflict creates. This requires significant new domestic and international (e.g., United Nations High Commissioner for Refugees) policy and practises for providing cancer care in today's contemporary conflict ecosystems that frequently cross national borders.

Keywords: Afghanistan, Pakistan, cancer, migration, conflict and health, global health

\section{Introduction}

Armed conflicts cause massive disruption including loss of life, injuries, the destruction of vital infrastructure and forced migration, with all the resulting short and long term socioeconomic, political and health consequences. The world is witnessing the highest levels of human displacement due to persecution, conflict and human rights abuses in modern
Correspondence to: Muhammed Aasim Yusuf Email: aasim@skm.org.pk

ecancer 2020, 14:1018

https://doi.org/10.3332/ecancer.2020.1018

Published: 05/03/2020

Received: 22/11/2019

Publication costs for this article were supported by ecancer (UK Charity number 1176307).

Copyright: $(\subset$ the authors; licensee ecancermedicalscience. This is an Open Access article distributed under the terms of the Creative Commons Attribution License (http:// creativecommons.org/licenses/by/3.0), which permits unrestricted use, distribution, and reproduction in any medium, provided the original work is properly cited. 
history with approximately 65.6 million refugees and displaced people worldwide in 2016 [1]. The international community has managed multiple refugee crises, mostly through United Nations (UN) agencies and non-governmental organisations providing acute medical care as well as controlling public health issues such as malnutrition and infectious disease outbreaks. However, non-communicable diseases (NCDs) affecting refugee and migrant populations, especially cancer, have received little attention both politically, and within the ecosystem of humanitarian medicine [2].

Migrant populations are usually unfamiliar with health systems in other countries and are often not enrolled in formal healthcare programmes $[3,4]$. In some countries, such as Lebanon, refugees only receive secondary or tertiary care if funded by the United Nations High Commissioner for Refugees (UNHCR); with an 83\% funding deficit, the UNHCR can only afford to fund few cancer cases [5]. Globally, most of the burden for caring for migrant populations including refugees with cancer falls on host countries and on out-of-pocket payments.

Pakistan shares a long, and in places, still disputed border with Afghanistan. Following the invasion of Afghanistan by the Union of Soviet Socialist Republics in 1979, millions of people from Afghanistan crossed this border to seek refuge in Pakistan [1]. At its peak, the refugee population within Pakistan numbered over 3.3 million people [1]. The continuation of conflict within Afghanistan since 2001 coupled to the poor healthcare infrastructure has meant that Afghan migrants continue to cross borders to present within Pakistan along ill-defined and complex therapeutic geographies, as seen in other conflict-affected countries [6]. In addition to a variety of smaller public and many private hospitals, Afghan migrants increasingly present to major apex cancer centres such as the Shaukat Khanum Memorial Cancer Hospital and Research Centre, Lahore.

\begin{tabular}{|l|}
\hline PANEL A: PATIENT SELECTION CRITERIA \\
\hline SKMCH\&RC accepts patients based on diagnosis and cancer stage with an \\
emphasis on accepting those most likely to be curable. \\
PANEL B: SUPPORTING AFGHAN PATIENTS \\
\hline ACCOMMODATION \\
Most chemotherapy and radiation treatments provided at SKMCH\&RC are elec- \\
tive/outpatient procedures requiring many patients to seek temporary accom- \\
modation near one of our hospitals. \\
Many patients, including Afghan patients, are unable to afford private accommo- \\
dation, leading to the emergence of SKMCH\&RC-affiliated hostel facilities which \\
provide free accommodation and meals as well as individual carer support, for up \\
to 300 patients. \\
For geographical reasons, staff and many patients who access these facilities \\
speak Pashto and Farsi which helps provide informal psychosocial support and \\
may help ameliorate the difficulties these patients face. \\
WALK-IN CLINICS \\
SKMCH\&RC also operates a network of walk-in clinics all over Pakistan which \\
patients with a suspected or established cancer diagnosis can attend for further \\
management. \\
There are an estimated 170,000 to 200,000 new cancer diagnoses every year in \\
Pakistan. In 2017 almost 45,000 new cancer patients attended one of our walk- \\
in clinics seeking treatment.
\end{tabular}

Nearly $30 \%$ of all patients seen in the hospital in Lahore come from Khyber Pakhtunkhwa, the adjoining tribal areas of Pakistan, and from Afghanistan. Yet little is known about the clinical, geographic and socio-demographic features of migrants of Afghan origin. Here, we present a retrospective unselected hospital registry analysis of these patients to understand and illuminate the complex socio-demographics, geography and care of such migrant populations seeking care in a host country. 


\section{Methods}

SKMCH\&RC uses a custom-built electronic medical record system which includes modules for patient registration, clinical information, order entry and viewing of results, as well as critical alerts.

Since 2000, all patient data has been entered directly into this system, with paper charts prior to this having been scanned and archived into the system [7]. Data of patients registered between 1st December 1995 and 1st December 2017 were collected to identify cancer patients over a 22-year period who were either identified as Afghan nationals or provided an Afghan address at the time of initial registration.

A retrospective review was performed by two independent reviewers, looking at patient demographics, including address within Afghanistan, sex, cancer diagnosis, stage, treatment provided and follow-up data, where available.

\section{Results}

A total of 4,039 patients were identified as Afghan nationals, i.e., having provided an Afghan address at the time of initial registration between 1995 and 2017. This represents $4.84 \%$ of all new patients ( $n=83,477$ ) seen at SKMCH\&RC [8]. 550 of these patients did not receive any further care at SKMCH\&RC for various reasons including the diagnosis of benign disease and not returning for follow-up after being requested to obtain further diagnostic investigations. Final analysis is based on the remaining 3,489 patients of which $87.4 \%$ had an address in Afghanistan (Table A1).

The mean age at presentation was 42.7 years and median age was 45 years. $60 \%$ of patients were male and $12 \%$ were children aged $\leq 19$-year old (Figure 1A). There was a rapid increase in the number of Afghan migrants presenting from 2008 onwards, coinciding with a major increase in conflict in Afghanistan (Figure 1B).
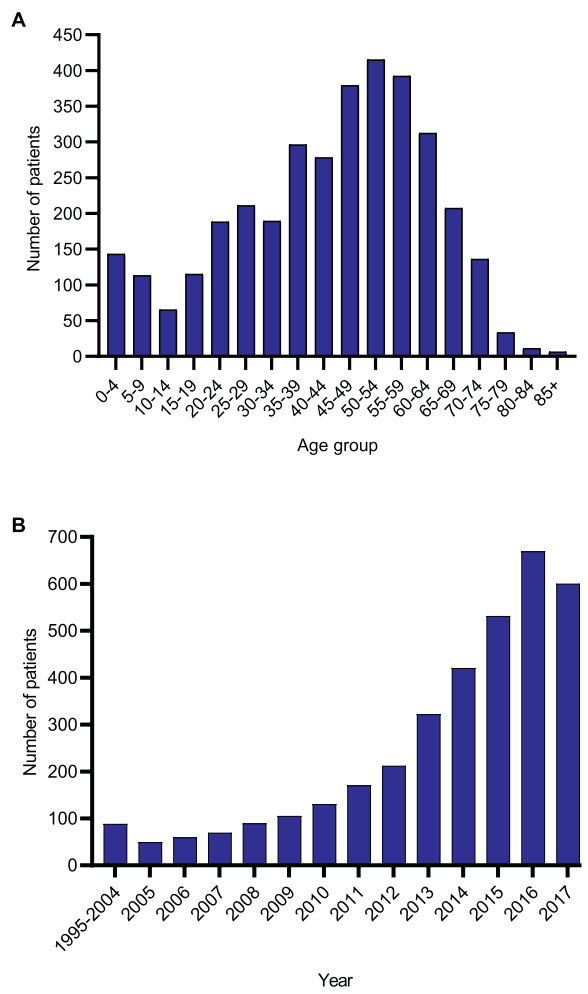

Figure 1. Afghan migrants treated at SKMCH\&RC $(n=3,489)$ from 1995 to 2017. (A) Age distribution. (B) Frequency of Afghan patients by year. 
The largest number came from Kabul (20.9\%) followed by Nangarhar (9.3\%), Balkh (6.2\%), Ghazni (5.3\%) and Herat (5.3\%) (Figure 2, Table A6). The province of origin for $19.3 \%$ of patients was unknown. The largest number of paediatric patients also came from Kabul (21.2\%) followed by Nangarhar (12.7\%), Balkh (7.4\%) and Khost (5.8\%). The province of origin for $19.2 \%$ of paediatric patients was unknown (Figure 2, Table A6). Data on distribution by gender has been provided in Table A7.

Driving times between Lahore, Pakistan and various provinces of Afghanistan from which the majority of Afghan migrants originated were estimated (from Google Maps"') were calculated as follows: 11-15 hours for Kabul; 8-13 hours for Nangarhar; 17 hours for Balkh; 13-14 hours for Ghazni and 23-26 hours for Herat. Each of the other provinces together accounted for less than $5 \%$ of the patients.

Upper gastrointestinal malignancies, including oesophageal (23\%) and gastric cancer (12.1\%), were the most common cancers $(n=3,489)$, followed by breast (7\%) and colorectal cancer (6\%) (Figure 3A). Haematological malignancies, including Hodgkin lymphoma (20.1\%), acute lymphoblastic leukaemia (18\%) and non-Hodgkin lymphoma (16.3\%), were the most common cancers in paediatric cases $(n=417)$ (Figure 3B).

Further analysis of adult patients revealed that $42 \%$ of male patients and $36.8 \%$ of female patients presented with Upper GI malignancies. $20.1 \%$ of female patients presented with breast cancer. Male genital, gynaecological, lower $\mathrm{Gl}$ and oropharyngeal malignancies were the next most common cancers among adult males and females (Table 1a).
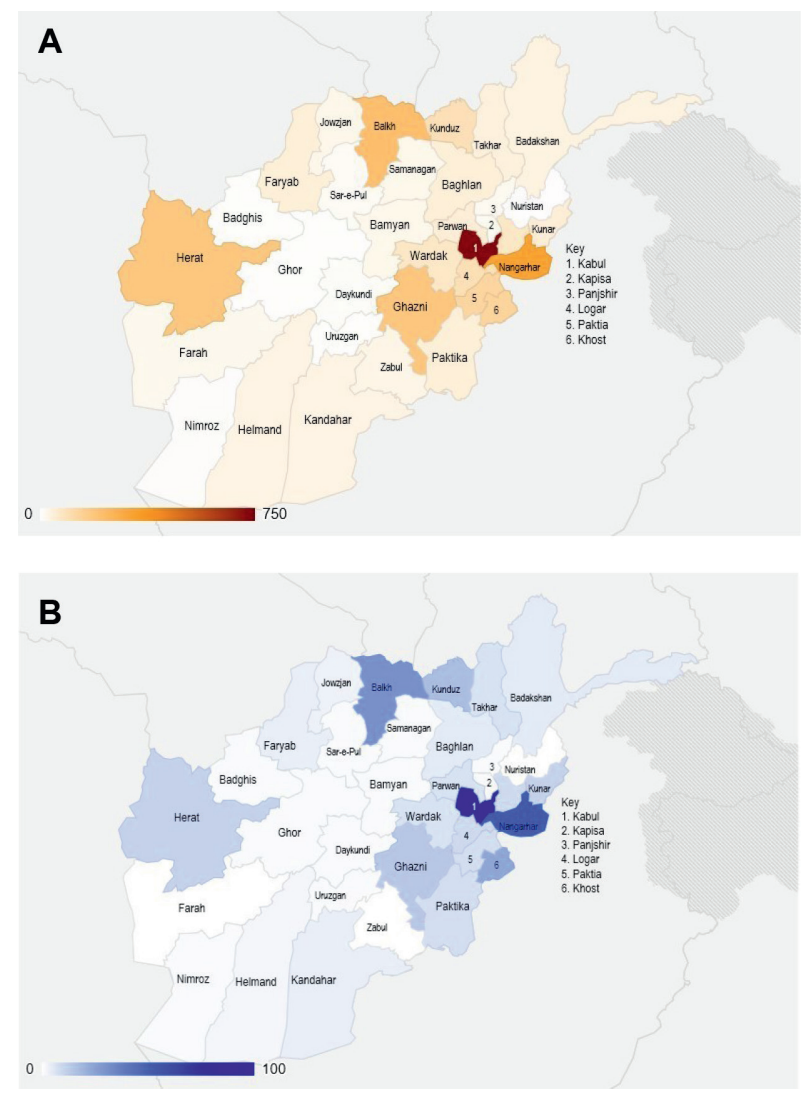

Figure 2. Distribution of patients by province of origin in Afghanistan. (A) Overall. (B) Paediatric only. 
A

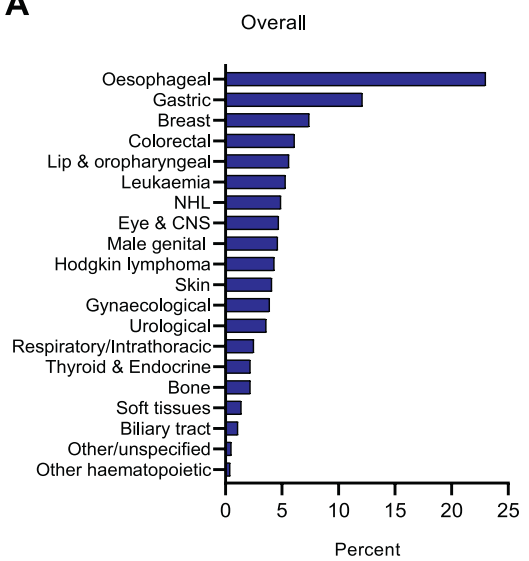

B

Paediatric

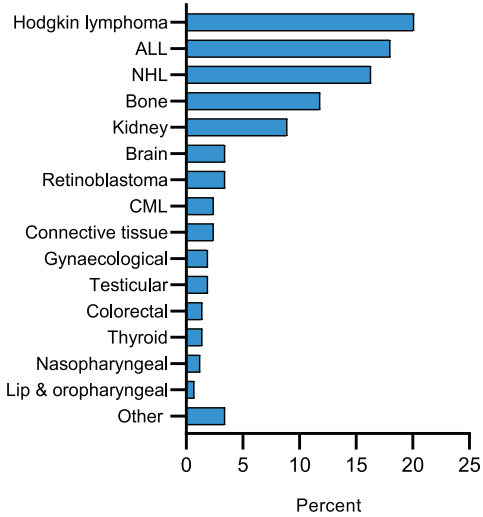

Figure 3. Distribution by site. (A) Overall (B) Paediatric. ALL: acute lymphoblastic leukaemia; CML: chronic myeloid leukaemia; CNS: central nervous system; NHL: non-Hodgkin lymphoma.

Table 1a. Distribution of adult patients by cancer type and gender.

\begin{tabular}{|l|c|c|}
\hline \multirow{2}{*}{\multicolumn{1}{|c|}{ Cancer type }} & \multicolumn{2}{c|}{ No. (\%) } \\
\cline { 2 - 3 } & $\begin{array}{c}\text { Male } \\
(n=1,801)\end{array}$ & $\begin{array}{c}\text { Female } \\
(\boldsymbol{n}=1,271)\end{array}$ \\
\hline Upper GI & $757(42.0)$ & $468(36.8)$ \\
\hline Breast & $2(0.1)$ & $255(20.1)$ \\
\hline Genital organs & $153(8.5)$ & $124(9.8)$ \\
\hline Lower GI & $145(8.1)$ & $61(4.8)$ \\
\hline Lip, oral cavity and pharynx & $130(7.2)$ & $58(4.6)$ \\
\hline Skin & $103(5.7)$ & $40(3.1)$ \\
\hline Eye and CNS & $84(4.7)$ & $53(4.2)$ \\
\hline Non-Hodgkin lymphoma & $73(4.1)$ & $29(2.3)$ \\
\hline Respiratory system and intrathoracic organs & $68(3.8)$ & $16(1.3)$ \\
\hline Renal and urinary system & $66(3.7)$ & $23(1.8)$ \\
\hline Hodgkin lymphoma & $43(2.4)$ & $22(1.7)$ \\
\hline Chronic myeloid leukaemia & $28(1.6)$ & $25(2.0)$ \\
\hline Soft tissues & $23(1.3)$ & $17(1.3)$ \\
\hline Chronic lymphocytic leukaemia & $22(1.3)$ & $3(0.2)$ \\
\hline Biliary tract & $24(1.3)$ & $14(1.1)$ \\
\hline Thyroid and other endocrine glands & $21(1.2)$ & $49(3.9)$ \\
\hline Bone & $22(1.2)$ & $6(0.5)$ \\
\hline Acute lymphoblastic leukaemia & $12(0.7)$ & $4(0.3)$ \\
\hline Other and unspecified & $3(0.5)$ & $2(0.2)$ \\
\hline Other haematopoietic & $2(0.2)$ \\
\hline Other leukaemia & $0(0.0)$ \\
\hline
\end{tabular}


As discussed above, haematological malignancies were the most common cancers affecting paediatric patients. Hodgkin lymphoma (23.8\%) was the most common cancer affecting male children, whereas acute lymphoblastic leukaemia (17.1\%) was the most common cancer affecting female children. Bone cancer, renal and urinary system and eye and central nervous system malignancies were the next most common cancers affecting male children whereas bone, renal and urinary system and gynaecological malignancies were the next most common cancers affecting female children (Table $1 \mathrm{~b})$.

$55.7 \%$ of all patients $(n=3,489)$ presented with advanced disease (Stage III and IV) and in 17.4\%, cancer stage was not documented. Further analysis of the cohort by age group revealed that $58 \%$ of adults and $39.1 \%$ of paediatric patients presented with advanced disease. Cancer stage for $14.7 \%$ of adults and $37.2 \%$ of paediatric patients was not documented.

Overall, $52.7 \%$ of patients, including $53.9 \%$ of adults and $43.2 \%$ of paediatric patients, were lost to follow-up likely due to travel requirements. $30.4 \%$ of adult and $29.5 \%$ of paediatric patients were being actively followed up. $6.9 \%$ of adults and $15.1 \%$ of paediatric patients had died during the study period. Further analysis for cancer stage and patient outcomes by gender is presented in Table A8.

Patients received a range of treatments in keeping with the heterogeneity of cancer diagnoses (Figure 4, Table 3a). More than two-thirds of patients were treated with chemotherapy or a combination of chemotherapy (CTX) and radiotherapy (XRT). Other treatment options included surgery, hormone therapy (HTX) and immunotherapy. 33.2\% of the overall study cohort achieved a complete response, $10.8 \%$ partially responded to therapy, $7.8 \%$ had stable disease and $27.8 \%$ relapsed or had progressive disease (Table A2). We were unable to assess disease outcome in $20.3 \%$ of patients. $42 \%$ of paediatric patients achieved a complete response to therapy, $10.3 \%$ partially responded, $4.6 \%$ had stable disease and $17.3 \%$ relapsed or had progressive disease. We were unable to assess disease outcome in $25.9 \%$ of paediatric patients (see Tables A3 and A4 for treatment outcomes for male and female adult patients, respectively, and Table A5 for the paediatric migrant population). More than two-thirds of paediatric patients were treated with CTX alone, in keeping with the nature of cancer diagnoses (Figure A1, Table 3b).

Table 1b. Distribution of paediatric patients by cancer type and gender.

\begin{tabular}{|l|c|c|}
\hline \multirow{2}{*}{\multicolumn{1}{|c|}{ Cancer type }} & \multicolumn{2}{c|}{ No. (\%) } \\
\cline { 2 - 3 } & Male & Female \\
\cline { 2 - 3 } & $(\boldsymbol{n}=\mathbf{2 9 4 )}$ & $(\boldsymbol{n}=123)$ \\
\hline Hodgkin lymphoma & $70(23.8)$ & $14(11.4)$ \\
\hline Acute lymphoblastic leukaemia & $54(18.4)$ & $21(17.1)$ \\
\hline Non-Hodgkin lymphoma & $54(18.4)$ & $14(11.4)$ \\
\hline Bone & $33(11.2)$ & $16(13.0)$ \\
\hline Renal and urinary system & $22(7.5)$ & $15(12.2)$ \\
\hline Eye and CNS & $21(7.1)$ & $7(5.7)$ \\
\hline Genital organs & $8(2.7)$ & $11(8.9)$ \\
\hline Chronic myeloid leukaemia & $8(2.7)$ & $2(1.6)$ \\
\hline Lip, oral cavity and pharynx & $6(2.0)$ & $3(2.4)$ \\
\hline Lower Gl & $5(1.7)$ & $1(0.8)$ \\
\hline Thyroid and other endocrine glands & $5(1.7)$ & $3(2.4)$ \\
\hline Soft tissues & $2(0.7)$ & $8(6.5)$ \\
\hline Other leukaemia & $3(1.0)$ & $1(0.8)$ \\
\hline Other and unspecified & $2(0.7)$ & $2(1.6)$ \\
\hline Respiratory system and intrathoracic & $1(0.3)$ & $1(0.8)$ \\
\hline organs & $0(0.0)$ & $1(0.8)$ \\
\hline Upper Gl & $0(0.0)$ & $1(0.8)$ \\
\hline Biliary tract & $0(0.0)$ & $2(1.6)$ \\
\hline Other haematopoietic & & \\
\hline
\end{tabular}


Table 2a. Distribution of study cohort by cancer stage.

\begin{tabular}{|l|c|c|}
\hline \multirow{2}{*}{\multicolumn{1}{|c|}{ Cancer stage }} & \multicolumn{2}{c|}{ No. (\%) } \\
\cline { 2 - 3 } & Adults $(\boldsymbol{n}=3,072)$ & Paediatric $(\boldsymbol{n}=417)$ \\
\hline Stage 0 & $6(0.2)$ & $0(0.0)$ \\
\hline Stage I & $258(8.4)$ & $44(10.6)$ \\
\hline Stage II & $578(18.8)$ & $55(13.2)$ \\
\hline Stage III & $1172(38.2)$ & $86(20.6)$ \\
\hline Stage IV & $607(19.8)$ & $77(18.5)$ \\
\hline Unknown/not applicable & $451(14.7)$ & $155(37.2)$ \\
\hline
\end{tabular}

Table 2b. Distribution of study cohort by select outcomes.

\begin{tabular}{|l|c|c|}
\hline \multirow{2}{*}{ Select outcomes } & \multicolumn{2}{c|}{ No. (\%) } \\
\cline { 2 - 3 } & Adults $(\boldsymbol{n}=3,072)$ & Paediatric $(\boldsymbol{n}=417)$ \\
\hline Active follow-up & $935(30.4)$ & $123(29.5)$ \\
\hline Active treatment & $187(6.1)$ & $33(7.9)$ \\
\hline Discharged & $80(2.6)$ & $18(4.3)$ \\
\hline Died & $213(6.9)$ & $63(15.1)$ \\
\hline
\end{tabular}

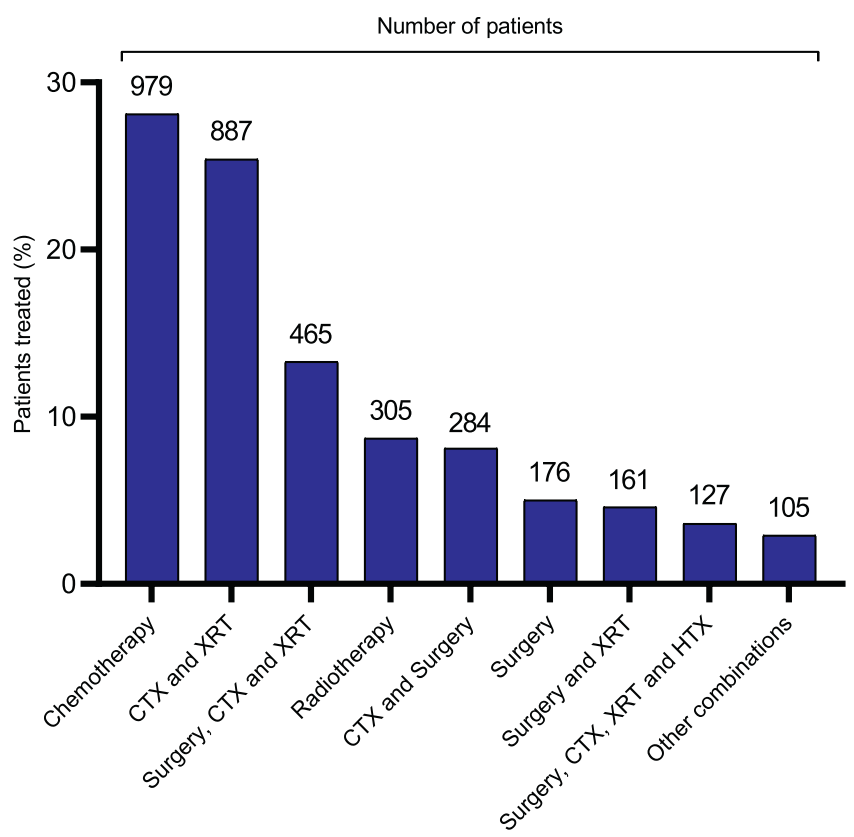

Figure 4. Distribution by treatment strategy. 
Table 3a. Treatment data for the most common cancers affecting adults. CTX = chemotherapy, XRT = radiotherapy, HTX = hormone therapy.

\begin{tabular}{|c|c|c|c|c|c|}
\hline & $\begin{array}{l}\text { Upper GI } \\
(n=1,225)\end{array}$ & $\begin{array}{c}\text { Breast } \\
(n=257)\end{array}$ & $\begin{array}{l}\text { Lower GI } \\
(n=206)\end{array}$ & $\begin{array}{l}\text { Lip, oral cavity and pharynx } \\
\qquad(n=188)\end{array}$ & $\begin{array}{l}\text { Male genital } \\
\quad(n=153)\end{array}$ \\
\hline Chemotherapy & 308 & 10 & 47 & 7 & 47 \\
\hline Radiotherapy & 37 & 5 & 3 & 36 & 2 \\
\hline Surgery & 13 & 4 & 16 & 2 & 10 \\
\hline $\mathrm{CTX}+\mathrm{XRT}$ & 481 & 8 & 48 & 107 & 5 \\
\hline CTX+Surgery & 103 & 21 & 26 & 1 & 29 \\
\hline XRT+Surgery & 6 & 2 & 1 & 24 & 4 \\
\hline $\mathrm{CTX}+\mathrm{XRT}+$ Surgery & 276 & 43 & 62 & 11 & 4 \\
\hline Hormone therapy & - & 1 & - & - & 21 \\
\hline $\mathrm{HTX}+\mathrm{CTX}$ & - & 2 & - & - & 3 \\
\hline $\mathrm{HTX}+\mathrm{XRT}$ & - & - & - & - & 10 \\
\hline HTX+Surgery & - & 5 & 1 & - & 10 \\
\hline HTX+CTX+Surgery & - & 21 & - & - & 1 \\
\hline $\mathrm{HTX}+\mathrm{CTX}+\mathrm{XRT}$ & - & 14 & - & - & 6 \\
\hline $\begin{array}{l}\mathrm{HTX}+\mathrm{CTX}+\mathrm{XRT} \\
+ \text { +Surgery }\end{array}$ & 1 & 121 & 2 & - & 1 \\
\hline
\end{tabular}

Table 3b. Treatment data for the most common cancers affecting children. CTX = chemotherapy, XRT = radiotherapy.

\begin{tabular}{|l|c|c|c|c|c|}
\hline & $\begin{array}{c}\text { Leukaemia } \\
(\mathbf{n}=\mathbf{8 9})\end{array}$ & $\begin{array}{c}\text { Hodgkin lymphoma } \\
(\boldsymbol{n}=\mathbf{8 4})\end{array}$ & $\begin{array}{c}\text { Non-Hodgkin lymphoma } \\
(\boldsymbol{n}=\mathbf{6 8})\end{array}$ & $\begin{array}{c}\text { Bone } \\
(\boldsymbol{n}=49)\end{array}$ & $\begin{array}{c}\text { Renal and Urinary organs } \\
(\boldsymbol{n}=37)\end{array}$ \\
\hline Chemotherapy & 89 & 66 & 63 & 11 & 11 \\
\hline Radiotherapy & - & - & 2 & - & - \\
\hline Surgery & - & - & - & 1 & 2 \\
\hline CTX+XRT & - & 17 & 2 & 6 & 7 \\
\hline CTX+Surgery & - & 1 & - & 7 & 10 \\
\hline $\begin{array}{l}\text { CTX+XRT } \\
+ \text { Surgery }\end{array}$ & - & 1 & & & 7 \\
\hline
\end{tabular}

\section{Discussion}

NCDs, which include the spectrum of cancers, are predicted to constitute over $80 \%$ of the global burden of disease by 2020 and will disproportionately affect Low- and Middle-Income Countries, especially refugee populations, with damaging long-term health and socio-economic consequences [9-11]. This is particularly relevant for conflict-affected regions which face a triple burden of disease encompassing communicable diseases, NCDs and trauma with limited healthcare resources and constant insecurity [2, 12, 13].

This study provides a basic demographic and clinical profile for Afghan cancer patients who were treated between 1995 and 2017 at SKMCH\&RC. The majority of patients presenting to our institution from Afghanistan were treatment naïve. Most patients underwent initial investigations in Afghanistan, including a biopsy, to establish a cancer diagnosis. Although some patients underwent surgical treatment, we rarely encountered patients who had received chemotherapy, and there are currently no functional radiotherapy facilities in Afghanistan. 
A significant proportion of Afghan patients presented at an advanced stage of disease. The most common cancers among adult patients in our cohort were upper gastrointestinal, breast and colorectal malignancies, whereas most paediatric patients presented with haematological malignancies (Figure 3). These findings are similar to previous studies investigating cancer among Afghan refugees in Iran and Pakistan $[10,11,14]$. The aetiology of cancer is complex but risk factors, including environmental exposure to munitions and the toxic remnants of war, poor dietary and lifestyle habits, including the heavy use of tobacco-based products such as naswar, and the lack of cancer surveillance programmes likely contribute to the development of cancer in this population [11, 15-18].

Over forty years of conflict has decimated Afghanistan's health infrastructure and there is minimal data on the burden of disease or resource allocation in the country $[19,20]$. The lack of a cancer surveillance programme, the cost of treatment, as well as lack of knowledge about cancer treatments lead to significant delays in patients seeking medical attention and presenting with advanced disease. The situation is exacerbated by on-going conflict and insecurity, financial hardship and limited access to follow-up or definitive treatment [11].

Our data shows that there was a steep rise in the number of Afghan patients presenting to SKMCH\&RC in the early 2000s. It is plausible that due to a period of relative peace in the mid-to-late 1990s fewer Afghan patients presented to Pakistan for cancer treatment. In addition, border controls at the Afghanistan-Pakistan border were virtually non-existent and Afghan nationals were able to buy and rent property in Pakistan with fewer restrictions.

There are clearly large numbers of patients needing cancer treatment within Afghanistan, many of whom are currently forced to travel long distances to seek treatment elsewhere. The journey is often dangerous and arduous, given the on-going conflict in various parts of Afghanistan. Patients often travel with several relatives, adding to overall cost as well as causing significant disruption to family life at home. Pakistan has also implemented stricter border controls since 2016 and Afghan patients are now universally required to obtain a visa to enter Pakistan which has added to the difficulties facing these patients. Most visas are issued for periods of 2-4 weeks at a time, and patients undergoing prolonged treatment must shuttle back and forth to renew their visas. Consequently, many patients miss appointments for investigations, treatment, or for follow-up which may explain the high loss to follow-up in our cohort, and our inability to assess disease outcome for $20.3 \%$ of our cohort, including $25.3 \%$ of paediatric patients.

Nevertheless, there is a trend towards increased care-seeking among Afghan patients highlighted by the steady rise of Afghan patients presenting to SKMCH\&RC (Figure 1b). This may reflect increased awareness of cancer among Afghans and the impact of the international presence in Afghanistan, including on-going capacity-building efforts between health organisations such as the World Health Organisation and the Afghan government [21], but it may also be because more patients in Afghanistan are aware of the services provided by SKMCH\&RC, including the fact that free treatment is offered to the majority of patients (Panel A). We also note that a significant proportion of patients present from Afghan provinces that are not geographically contiguous with Pakistan, such as Balkh and Herat, which are much closer to Iran (Figure 2). Afghan patients may choose to be treated at SKMCH\&RC because it allows unrestricted access to Afghan patients and provides free cancer treatment to all patients experiencing financial hardship. Anecdotally, Afghan patients report that procuring a visa to enter Iran is also significantly more difficult than for Pakistan.

Iraq and Syria face a similar situation with conflict displacing millions of people and destroying the local oncology infrastructure [2, 22]. In Syria alone, more than half of all public hospitals have been damaged or destroyed and there are no diagnostic imaging or radiation therapy facilities available, resulting in more than $45 \%$ of Syrian patients being unable to complete their treatment in Syria [23, 24]. In Iraq, which once had a robust oncology programme, hospitals face critical pharmaceutical shortages resulting in limited doses of chemotherapy per patient [24]. This has forced people to piece together cancer care across domestic and international boundaries whilst navigating personal illness, financial hardship, threats of violence as well as visa and security/checkpoint restrictions as seen in Afghanistan [22, 26].

The conflict in Afghanistan has impaired the development of its health infrastructure and the displacement of millions of people which has placed a substantial burden on host countries' healthcare systems. As discussed above, a significant proportion of Afghan patients presented with advanced cancers, including tumours that are significantly cheaper and easier to treat if they were detected at an earlier stage.

It is imperative that all stakeholders invest in developing a robust national cancer screening and awareness programme, which is currently lacking in Afghanistan. Funding cancer care for refugees has historically been neglected with resources and funding directed towards more acute treatments. The funding deficit is compounded by the misconception that all types of cancer have poor prognoses. Several commentators have advocated using national cancer registries to achieve better surveillance and allow forecasting of crises so that aid from international organisations can be requested beforehand. Public awareness, including information on when and where to seek help, should be made 
available to help detect and treat early stage cancer which is less costly and carries better prognosis [4, 27]. In addition to increasing funding for secondary and tertiary care, primary prevention and cancer surveillance strategies incorporating mobile health clinics and civil society organisations with a model akin to the Sendai Framework for Disaster Risk Reduction should be considered [4]. Afghanistan can also benefit from initiatives aimed at improving cancer control in the Muslim world such as the Programme of Action for Cancer Therapy, a collaborative effort between the International Atomic Energy Agency, the Organisation of Islamic Cooperation (OIC) and the Islamic Development Bank to bolster radiation medicine facilities, provide technical support and improve cancer care infrastructure among the 57 member states of the OIC [28].

\section{Limitations}

This study has some important limitations. The use of paper records before 2000 , as well as relatively limited data being requested from patients in earlier years, may have resulted in a number of Afghan patients being treated without being identified. Less stringent border controls before 2016 enabled many Afghan families to live in Pakistan in a state of semi-permanent residence without being formally registered or documented, and Afghan patients were able to enter and leave Pakistan with relative ease. As a result, the actual numbers of Afghan patients treated at SKMCH\&RC may have been underestimated. Finally, we have used the provision of an Afghan address as a permanent place of residence as a surrogate for Afghan nationality. While there is no way of knowing whether this is accurate, we do not feel that this is likely to be a source of major discrepancy in the numbers we have provided.

\section{Conclusions}

\begin{tabular}{|l|}
\hline PANEL C: ESTABLISHING A CANCER CENTRE IN AFGHANISTAN \\
\hline SKMCH\&RC is currently engaged in discussions with the Government of \\
Afghanistan to help to establish a national cancer centre in Kabul. We will be \\
focusing our efforts on: \\
- Training Afghan physicians, nurses and allied healthcare professionals. \\
- Establishing a population-based cancer registry starting in Kabul and eventu- \\
ally extending to the rest of Afghanistan. \\
With more pressing and visible concerns such as primary care, maternal care and \\
childhood vaccination programmes, cancer treatment often loses out. The WHO \\
EMRO and other donor agencies should support such initiatives in the medium- \\
to long-term to help address cancer care needs in Afghanistan. \\
\hline
\end{tabular}

While the exact magnitude of the cancer problem in Afghanistan is unknown, this is the largest dataset of Afghan cancer patients to date. We feel our data is important in drawing attention to the possible scale of the problem and highlights the importance of further work in understanding the aetiology and epidemiology of cancer in Afghanistan as well the establishment of cancer services in the country. We have attempted to draw attention to the problem of cancer diagnosis and treatment in Afghanistan and to provide some initial data as to incidence, tumour types, most common age at presentation and regional distribution in our cohort. There may also be important differences in cancer incidence, at least between Afghanistan and Pakistan, not previously noted.

Future research should concentrate on building a clearer understanding of the incidence and prevalence of cancers within Afghanistan assess the impact of dietary and lifestyle habits within the Afghan population, as well as environmental factors including the effects of munitions and the toxic remnants of war. Further work is also needed to identify barriers to cancer care-seeking among the Afghan population including cultural and societal factors to better inform cancer control policy and tailor cancer awareness campaigns in the country.

Our data is likely to be helpful for national health policy planners, as well as for international funding agencies, such as the UNHCR and others. We have also provided data on the possible distribution of cancers within this population. Our data provides important preliminary information for health care policy planners, as well as for donor agencies within Afghanistan, especially given the paucity of information 
currently available. The nascent efforts now underway to establish cancer services in Afghanistan, with which we are involved, will hopefully form the nucleus around which such services can be planned in the future.

\section{List of abbreviations}

$\begin{array}{ll}\text { ALL } & \text { Acute lymphoblastic leukaemia } \\ \text { CML } & \text { Chronic myeloid leukaemia } \\ \text { CNS } & \text { Central nervous system } \\ \text { CTX } & \text { Chemotherapy } \\ \text { EMRO } & \text { WHO Regional Office for the Eastern Mediterranean } \\ \text { GI } & \text { Gastrointestinal } \\ \text { HTX } & \text { Hormone therapy } \\ \text { NCD } & \text { Non-communicable disease } \\ \text { NHL } & \text { Non-Hodgkin lymphoma } \\ \text { OIC } & \text { Organisation of Islamic Cooperation } \\ \text { SKCMH\&RC } & \text { Shaukat Khanum Memorial Cancer Hospital and Research Centre } \\ \text { UN } & \text { United Nations } \\ \text { UNHCR } & \text { United Nations High Commissioner for Refugees } \\ \text { XRT } & \text { Radiotherapy }\end{array}$

\section{Conflicts of interest}

None to declare.

\section{Disclosure of results at a meeting}

None.

\section{Institutional review}

Shaukat Khanum Memorial Cancer Hospital and Research Centre Institutional Review Board Number: 07-07-17-21.

\section{Acknowledgments}

Colleagues in our cancer registry and clinical data management unit, together with information technology colleagues, collected data from the hospital's electronic medical records saved within the hospital information system of SKMCH\&RC.

\section{Funding}

This publication is funded through the UK Research and Innovation GCRF RESEARCH FOR HEALTH IN CONFLICT (R4HC-MENA); developing capability, partnerships and research in the Middle and Near East (MENA) ES/P010962/1. 


\section{References}

1. UNHCR (2017). UNHCR-The UN Refugee Agency. Global Trends: Forced displacement in 2017 [Internet] [https://www.unhcr. org/5b27be547.pdf] Date accessed: 29/04/19

2. El Saghir NS, Soto Pérez de Celis E, and Fares JE, et al (2018) Cancer care for refugees and displaced populations: Middle East conflicts and global natural disasters Am Soc Clin Oncol Educ B 38 433-440 https://doi.org/10.1200/EDBK_201365

3. Spiegel P, Khalifa A, and Mateen FJ (2014) Cancer in refugees in Jordan and Syria between 2009 and 2012: challenges and the way forward in humanitarian emergencies Lancet Oncol 15(7) e290-e297 https://doi.org/10.1016/S1470-2045(14)70067-1 PMID: 24872112

4. El Saghir NS, Abou-Sitta G, and Kaddoura I (2017) Conflict Medicine and Cancer Care in Refugees and Displaced People [Internet]. ASCO Connection [https://connection.asco.org/blogs/conflict-medicine-and-cancer-care-refugees-and-displaced-people] Date accessed: 29/04/2019

5. UNHCR (2017) UNHCR-The UN Refugee Agency. Global Focus; UNHCR Operations Worldwide. 3RP Regional Refugee and Resilience Plan 2018-2019, in response to the Syria crisis [Internet] [http://reporting.unhcr.org/node/19889] Date accessed: 29/04/2019

6. Dewachi O (2017) Ungovernable Life: Mandatory Medicine and Statecraft in Iraq (Palo Alto: Stanford University Press)

7. Sultan F, Aziz MT, and Khokhar I, et al (2014) Development of an in-house hospital information system in a hospital in Pakistan Int J Med Inform 83(3) 180-188 https://doi.org/10.1016/j.ijmedinf.2013.12.004 PMID: 24373713

8. Mahmood S, Faraz R, and Yousaf A, et al (2017) Collective Cancer Registry Report from December 1994 till December 2017, of the Shaukat Khanum Memorial Cancer Hospital \& Research Center, Pakistan [Internet] [https://shaukatkhanum.org.pk/wp-content/ uploads/2018/08/ccrr-1994-2017.pdf] Date accessed: 29/04/19

9. Boutayeb A and Boutayeb S (2005) The burden of non communicable diseases in developing countries Int J Equity Health 4(1) 2 https:// doi.org/10.1186/1475-9276-4-2 PMID: 15651987 PMCID: 546417

10. Otoukesh S, Mojtahedzadeh M, and Sherzai D, et al (2012) A retrospective study of demographic parameters and major health referrals among Afghan refugees in Iran Int J Equity Health 11(1) 82 https://doi.org/10.1186/1475-9276-11-82 PMID: 23256618 PMCID: 3547741

11. Otoukesh S, Mojtahedzadeh M, and Figlin RA, et al (2015) Literature review and profile of cancer diseases among Afghan refugees in Iran: referrals in six years of displacement Med Sci Monit Int Med J Exp Clin Res 213622

12. Macrae J, Zwi AB, and Gilson L (1996) A triple burden for health sector reform:'post'-conflict rehabilitation in Uganda Soc Sci Med 42(7) 1095-1108 https://doi.org/10.1016/0277-9536(95)00338-X PMID: 8730915

13. Alleyne G, Binagwaho A, and Haines A, et al (2013) Embedding non-communicable diseases in the post-2015 development agenda Lancet 381(9866) 566-574 https://doi.org/10.1016/S0140-6736(12)61806-6 PMID: 23410606

14. Khan SM, Gillani J, and Nasreen S, et al (1997) Pediatric tumors in north west Pakistan and Afghan refugees Pediatr Hematol Oncol 14(3) 267-272 https://doi.org/10.3109/08880019709009496 PMID: 9185211

15. Sanderson H, Fauser P, and Stauber RS, et al (2017) Civilian exposure to munitions-specific carcinogens and resulting cancer risks for civilians on the Puerto Rican island of Vieques following military exercises from 1947 to 1998 Glob Secur Heal Sci Policy 2(1) 40-61 https://doi.org/10.1080/23779497.2017.1369358

16. Sanati MP, Kumble S, and Hanieh S, et al (2014) Prevalence of dyslipidaemia and micronutrient deficiencies among newly arrived Afghan refugees in rural Australia: a cross-sectional study BMC Public Health 14896 https://doi.org/10.1186/1471-2458-14-896

17. Khan Z, Suliankatchi RA, and Heise TL, et al (2017) Naswar (smokeless tobacco) use and the risk of oral cancer in Pakistan: a systematic review with meta-analysis Nicotine Tob Res 21(1) 32-40 https://doi.org/10.1093/ntr/ntx281 
18. Bhatta DN, Hiatt RA, and Van Loon K, et al (2019) Exposure to household tobacco smoke and risk of cancer morbidity and mortality: analysis of data from the Afghanistan Demographic and Health Survey 2015 Prev Med (Baltim) 123 217-224 https://doi.org/10.1016/j. ypmed.2019.03.044

19. Carvalho N, Salehi AS, and Goldie SJ (2012) National and sub-national analysis of the health benefits and cost-effectiveness of strategies to reduce maternal mortality in Afghanistan Health Policy Plan 28(1) 62-74 https://doi.org/10.1093/heapol/czsO26 PMID: 22411880

20. WHO (2014) Cancer country profile: Afghanistan [Internet] [https://www.who.int/cancer/country-profiles/afg_en.pdf?ua=1]

21. WHO (2015) More effective strategies needed for cancer control: prevention and early detection are key [Internet] [http://www.emro. who.int/afg/afghanistan-news/world-cancer-day-2015.html] Date accessed 3/02/2020

22. Caduff C, Skelton M, and Banerjee D, et al (2018) Analysis of social science research into cancer care in low-and middle-income countries: improving global cancer control through greater interdisciplinary research J Glob Oncol 4 1-9 PMID: 30084699 PMCID: 6223507

23. WHO (2018) Emergencies: Syrian Arab Republic Humanitarian Response Plan 2018 [Internet] [https://www.who.int/emergencies/ response-plans/2018/syria/en/] Date accessed 29/04/2019

24. Abbara A, Blanchet K, and Sahloul Z, et al (2015) The effect of the conflict on Syria's health system and human resources for health World Health Popul 16(1) 87-95

25. Skelton M and Talabany SK (2017) War, Health \& Refugees in Iraq. Stakeholder Meeting Report [Internet] [https://auis.edu.krd/iris/ sites/default/files/War\%2C Health \%26 Refugees in Iraq_IRIS REPORT.pdf]

26. Dewachi O, Skelton M, and Nguyen V-K, et al (2014) Changing therapeutic geographies of the Iraqi and Syrian wars Lancet 383(9915) 449-457 https://doi.org/10.1016/S0140-6736(13)62299-0 PMID: 24452046

27. Anderson BO, Cazap E, and El Saghir NS, et al (2011) Optimisation of breast cancer management in low-resource and middleresource countries: executive summary of the Breast Health Global Initiative consensus, 2010 Lancet Oncol 12(4) 387-398 https://doi. org/10.1016/S1470-2045(11)70031-6 PMID: 21463833

28. Akinwande B and Nitzsche A (2018) The Programme of Action for Cancer Therapy of the International Atomic Energy Agency, the Islamic Development Bank, and the Organization of Islamic Cooperation J Global Oncol 4 186s-186s [https://ascopubs.org/doi/ abs/10.1200/jgo.18.65300] 


\section{Appendix}

Table A1. Distribution of study cohort by country of birth and country of residence.

\begin{tabular}{|l|c|c|c|}
\hline \multirow{2}{*}{ Country of residence } & \multicolumn{3}{|c|}{ Country of birth } \\
\cline { 2 - 4 } & Afghanistan & Pakistan & Total \\
\hline Afghanistan & 2,713 & 337 & 3,050 \\
\hline Pakistan & 439 & 0 & 439 \\
\hline Total & 3,152 & 337 & 3,489 \\
\hline
\end{tabular}

Table A2. Distribution of study cohort by treatment response.

\begin{tabular}{|l|l|l|}
\hline \multirow{2}{*}{ Treatment outcome } & \multicolumn{2}{c|}{ No. (\%) } \\
\cline { 2 - 3 } & \multicolumn{1}{|c|}{$\begin{array}{c}\text { Overall } \\
(n=3,489)\end{array}$} & \multicolumn{1}{|c|}{$\begin{array}{c}\text { Paediatric } \\
(n=417)\end{array}$} \\
\hline Complete response & $1,159(33.2)$ & $175(42.0)$ \\
\hline Partial response & $377(10.8)$ & $43(10.3)$ \\
\hline Stable disease & $273(7.8)$ & $19(4.6)$ \\
\hline Progression/Relapse & $970(27.8)$ & $72(17.3)$ \\
\hline Unknown & $710(20.3)$ & $108(25.9)$ \\
\hline
\end{tabular}

Table A3. Treatment outcomes and cancer stage for the top five cancers affecting adult male patients aged $\geq 19$-year old.

\begin{tabular}{|c|c|c|c|c|c|c|c|c|}
\hline \multirow{3}{*}{ Cancer diagnosis } & \multirow{3}{*}{ Treatment outcome } & \multicolumn{7}{|c|}{ Number of patients } \\
\hline & & \multicolumn{7}{|c|}{ Stage } \\
\hline & & 0 & I & II & III & IV & NK/NA & Total \\
\hline \multirow[t]{6}{*}{ Oesophageal } & Complete Response & - & 3 & 18 & 55 & 4 & 1 & 81 \\
\hline & Partial Response & - & 1 & 11 & 63 & 9 & 1 & 85 \\
\hline & Stable disease & - & 1 & 3 & 29 & 6 & 1 & 40 \\
\hline & Progression/Relapse & - & 1 & 15 & 94 & 28 & 4 & 142 \\
\hline & Unknown & - & 2 & 6 & 48 & 13 & 5 & 74 \\
\hline & Total & - & 8 & 53 & 289 & 60 & 12 & 422 \\
\hline \multirow[t]{6}{*}{ Stomach } & Complete Response & - & 3 & 14 & 31 & 5 & 0 & 53 \\
\hline & Partial Response & - & 1 & 8 & 21 & 11 & 1 & 42 \\
\hline & Stable disease & - & 0 & 10 & 22 & 14 & 0 & 46 \\
\hline & Progression/Relapse & - & 0 & 26 & 57 & 35 & 6 & 124 \\
\hline & Unknown & - & 0 & 7 & 35 & 22 & 6 & 70 \\
\hline & Total & - & 4 & 65 & 166 & 87 & 13 & 335 \\
\hline
\end{tabular}


Table A3. Treatment outcomes and cancer stage for the top five cancers affecting adult male patients aged $\geq 19$-year old. (Continued)

\begin{tabular}{|c|c|c|c|c|c|c|c|c|}
\hline \multirow[t]{6}{*}{ Colorectal } & Complete Response & - & 2 & 18 & 20 & 0 & 1 & 41 \\
\hline & Partial Response & - & 0 & 1 & 8 & 0 & 1 & 10 \\
\hline & Stable disease & - & 0 & 0 & 6 & 3 & 0 & 9 \\
\hline & Progression/Relapse & - & 1 & 3 & 37 & 14 & 1 & 56 \\
\hline & Unknown & - & 1 & 2 & 16 & 5 & 1 & 25 \\
\hline & Total & - & 4 & 24 & 87 & 22 & 4 & 141 \\
\hline \multirow[t]{6}{*}{ Skin } & Complete Response & 1 & 17 & 19 & 6 & 3 & 14 & 60 \\
\hline & Partial Response & 0 & 0 & 1 & 0 & 0 & 2 & 3 \\
\hline & Stable disease & 0 & 0 & 0 & 1 & 1 & 0 & 2 \\
\hline & Progression/Relapse & 0 & 3 & 5 & 4 & 0 & 7 & 19 \\
\hline & Unknown & 0 & 2 & 5 & 4 & 1 & 7 & 19 \\
\hline & Total & 1 & 22 & 30 & 15 & 5 & 30 & 103 \\
\hline \multirow[t]{6}{*}{ Testicular } & Complete Response & - & 19 & 4 & 5 & 0 & 3 & 31 \\
\hline & Partial Response & - & 1 & 1 & 12 & 1 & 0 & 15 \\
\hline & Stable disease & - & 1 & 2 & 9 & 0 & 0 & 12 \\
\hline & Progression/Relapse & - & 0 & 0 & 9 & 5 & 0 & 14 \\
\hline & Unknown & - & 3 & 3 & 7 & 0 & 0 & 13 \\
\hline & Total & - & 24 & 10 & 42 & 6 & 3 & 85 \\
\hline \multirow[t]{6}{*}{ Total } & Complete Response & 1 & 44 & 73 & 117 & 12 & 19 & 266 \\
\hline & Partial Response & 0 & 3 & 22 & 104 & 21 & 5 & 155 \\
\hline & Stable disease & 0 & 2 & 15 & 67 & 24 & 1 & 109 \\
\hline & Progression/Relapse & 0 & 5 & 49 & 201 & 82 & 18 & 355 \\
\hline & Unknown & 0 & 8 & 23 & 110 & 41 & 19 & 201 \\
\hline & Total & 1 & 62 & 182 & 599 & 180 & 62 & 1,086 \\
\hline
\end{tabular}

NK: not known, NA: not applicable.

Table A4. Treatment outcomes and cancer stage for the top five cancers affecting adult female patients aged $\geq 19$-year old.

\begin{tabular}{|c|c|c|c|c|c|c|c|c|}
\hline \multirow{3}{*}{ Cancer diagnosis } & \multirow{3}{*}{ Treatment outcome } & \multicolumn{7}{|c|}{ Number of patients } \\
\hline & & \multicolumn{7}{|c|}{ Stage } \\
\hline & & 0 & I & II & III & IV & NK/NA & Total \\
\hline \multirow[t]{6}{*}{ Oesophageal } & Complete Response & - & 7 & 16 & 69 & 4 & 2 & 98 \\
\hline & Partial Response & - & 0 & 8 & 44 & 14 & 0 & 66 \\
\hline & Stable disease & - & 0 & 1 & 27 & 3 & 1 & 32 \\
\hline & Progression/Relapse & - & 0 & 8 & 82 & 23 & 5 & 118 \\
\hline & Unknown & - & 0 & 7 & 57 & 3 & 1 & 68 \\
\hline & Total & - & 7 & 40 & 279 & 47 & 9 & 382 \\
\hline
\end{tabular}


Table A4. Treatment outcomes and cancer stage for the top five cancers affecting adult female patients aged $\geq 19$-year old. (Continued)

\begin{tabular}{|c|c|c|c|c|c|c|c|c|}
\hline \multirow[t]{5}{*}{ Breast } & Complete Response & 3 & 13 & 130 & 17 & 1 & 7 & 171 \\
\hline & Partial Response & 0 & 0 & 2 & 0 & 6 & 1 & 9 \\
\hline & Progression/Relapse & 0 & 0 & 18 & 8 & 9 & 1 & 36 \\
\hline & Unknown & 0 & 3 & 26 & 5 & 2 & 3 & 39 \\
\hline & Total & 3 & 16 & 176 & 30 & 18 & 12 & 255 \\
\hline \multirow[t]{6}{*}{ Stomach } & Complete Response & - & 0 & 4 & 10 & 1 & 0 & 15 \\
\hline & Partial Response & - & 0 & 1 & 7 & 3 & 1 & 12 \\
\hline & Stable disease & - & 0 & 4 & 6 & 5 & 0 & 15 \\
\hline & Progression/Relapse & - & 0 & 5 & 21 & 5 & 2 & 33 \\
\hline & Unknown & - & 0 & 1 & 6 & 4 & 0 & 11 \\
\hline & Total & - & 0 & 15 & 50 & 18 & 3 & 86 \\
\hline \multirow[t]{6}{*}{ Cervical/Uterine } & Complete Response & 1 & 9 & 13 & 1 & 3 & 2 & 29 \\
\hline & Partial Response & 0 & 0 & 6 & 1 & 3 & 0 & 10 \\
\hline & Stable disease & 0 & 1 & 1 & 1 & 0 & 0 & 3 \\
\hline & Progression/Relapse & 0 & 2 & 5 & 4 & 5 & 0 & 16 \\
\hline & Unknown & 0 & 0 & 5 & 3 & 2 & 0 & 10 \\
\hline & Total & 1 & 12 & 30 & 10 & 13 & 2 & 68 \\
\hline \multirow[t]{6}{*}{ Colorectal } & Complete Response & - & 0 & 11 & 11 & 0 & 0 & 22 \\
\hline & Partial Response & - & 0 & 0 & 2 & 1 & 0 & 3 \\
\hline & Stable disease & - & 0 & 1 & 5 & 1 & 0 & 7 \\
\hline & Progression/Relapse & - & 0 & 6 & 15 & 3 & 0 & 24 \\
\hline & Unknown & - & 0 & 0 & 4 & 0 & 1 & 5 \\
\hline & Total & - & 0 & 18 & 37 & 5 & 1 & 61 \\
\hline \multirow[t]{6}{*}{ Total } & Complete Response & 4 & 29 & 174 & 108 & 9 & 11 & 335 \\
\hline & Partial Response & 0 & 0 & 17 & 54 & 27 & 2 & 100 \\
\hline & Stable disease & 0 & 1 & 7 & 39 & 9 & 1 & 57 \\
\hline & Progression/Relapse & 0 & 2 & 42 & 130 & 45 & 8 & 227 \\
\hline & Unknown & 0 & 3 & 39 & 75 & 11 & 5 & 133 \\
\hline & Total & 4 & 35 & 279 & 406 & 101 & 27 & 852 \\
\hline
\end{tabular}

NK: not known, NA: not applicable.

Table A5. Treatment outcomes and cancer stage for the top five cancers affecting paediatric patients aged <19-year old.

\begin{tabular}{|c|c|c|c|c|c|c|c|}
\hline \multirow{3}{*}{ Cancer diagnosis } & \multirow{3}{*}{ Treatment outcome } & \multicolumn{6}{|c|}{ Number of patients } \\
\hline & & \multicolumn{6}{|c|}{ Stage } \\
\hline & & I & II & III & IV & NK/NA & Total \\
\hline \multirow[t]{5}{*}{ Hodgkin lymphoma } & Complete Response & - & 20 & 31 & 14 & - & 65 \\
\hline & Partial Response & - & 5 & 4 & 3 & - & 12 \\
\hline & Stable disease & - & 0 & 1 & 0 & - & 1 \\
\hline & Progression/Relapse & - & 0 & 2 & 4 & - & 6 \\
\hline & Total & - & 25 & 38 & 21 & - & 84 \\
\hline
\end{tabular}


Table A5. Treatment outcomes and cancer stage for the top five cancers affecting paediatric patients aged <19-year old. (Continued)

\begin{tabular}{|c|c|c|c|c|c|c|c|}
\hline \multirow[t]{4}{*}{ Acute lymphoblastic leukaemia } & Complete Response & - & - & - & - & 15 & 15 \\
\hline & Progression/Relapse & - & - & - & - & 8 & 8 \\
\hline & Unknown & - & - & - & - & 52 & 52 \\
\hline & Total & - & - & - & - & 75 & 75 \\
\hline \multirow[t]{6}{*}{ Non-Hodgkin lymphoma } & Complete Response & 3 & 8 & 17 & 3 & 0 & 31 \\
\hline & Partial Response & 0 & 0 & 7 & 6 & 0 & 13 \\
\hline & Stable disease & 0 & 0 & 0 & 1 & 0 & 1 \\
\hline & Progression/Relapse & 0 & 0 & 2 & 2 & 0 & 4 \\
\hline & Unknown & 0 & 2 & 5 & 11 & 1 & 19 \\
\hline & Total & 3 & 10 & 31 & 23 & 1 & 68 \\
\hline \multirow[t]{6}{*}{ Bone } & Complete Response & 8 & 1 & - & 3 & 0 & 12 \\
\hline & Partial Response & 3 & 0 & - & 2 & 1 & 6 \\
\hline & Stable disease & 1 & 1 & - & 0 & 2 & 4 \\
\hline & Progression/Relapse & 2 & 5 & - & 6 & 7 & 20 \\
\hline & Unknown & 2 & 2 & - & 1 & 2 & 7 \\
\hline & Total & 16 & 9 & - & 12 & 12 & 49 \\
\hline \multirow[t]{6}{*}{ Renal } & Complete Response & 1 & 2 & 1 & 2 & 6 & 12 \\
\hline & Partial Response & 0 & 0 & 0 & 4 & 2 & 6 \\
\hline & Stable disease & 0 & 1 & 0 & 0 & 1 & 2 \\
\hline & Progression/Relapse & 0 & 0 & 1 & 4 & 5 & 10 \\
\hline & Unknown & 1 & 1 & 0 & 2 & 3 & 7 \\
\hline & Total & 2 & 4 & 2 & 12 & 17 & 37 \\
\hline \multirow[t]{6}{*}{ Total } & Complete Response & 12 & 31 & 49 & 22 & 21 & 135 \\
\hline & Partial Response & 3 & 5 & 11 & 15 & 3 & 37 \\
\hline & Stable disease & 1 & 2 & 1 & 1 & 3 & 8 \\
\hline & Progression/Relapse & 2 & 5 & 5 & 16 & 20 & 48 \\
\hline & Unknown & 3 & 5 & 5 & 14 & 58 & 85 \\
\hline & Total & 21 & 48 & 71 & 68 & 105 & 313 \\
\hline
\end{tabular}

NK: not known, NA: not applicable.

Table A6. Distribution of study cohort by province of origin.

\begin{tabular}{|l|c|c|}
\hline \multirow{2}{*}{ Province } & \multicolumn{2}{|c|}{ No. (\%) } \\
\cline { 2 - 3 } & $\begin{array}{c}\text { Overall } \\
(\boldsymbol{n}=3,489)\end{array}$ & $\begin{array}{c}\text { Paediatric } \\
(\mathbf{n}=417)\end{array}$ \\
\hline Kabul & $730(20.9)$ & $88(21.1)$ \\
\hline Nangarhar & $325(9.3)$ & $53(12.7)$ \\
\hline Balkh & $216(6.2)$ & $31(7.4)$ \\
\hline Ghazni & $186(5.3)$ & $14(3.4)$ \\
\hline Herat & $184(5.3)$ & $11(2.6)$ \\
\hline Khost & $136(3.9)$ & $24(5.8)$ \\
\hline
\end{tabular}


Table A6. Distribution of study cohort by province of origin. (Continued)

\begin{tabular}{|c|c|c|}
\hline Paktia & $130(3.7)$ & $8(1.9)$ \\
\hline Kunduz & $94(2.7)$ & $17(4.1)$ \\
\hline Logar & $95(2.7)$ & $9(2.2)$ \\
\hline Laghman & $73(2.1)$ & $9(2.2)$ \\
\hline Wardak & $74(2.1)$ & $7(1.7)$ \\
\hline Baghlan & $48(1.4)$ & $5(1.2)$ \\
\hline Kunar & $50(1.4)$ & $11(2.6)$ \\
\hline Paktika & $49(1.4)$ & $8(1.9)$ \\
\hline Parwan & $50(1.4)$ & $7(1.7)$ \\
\hline Faryab & $47(1.3)$ & $4(1.0)$ \\
\hline Takhar & $41(1.2)$ & $7(1.7)$ \\
\hline Badakshan & $37(1.1)$ & $5(1.2)$ \\
\hline Kandahar & $32(0.9)$ & $4(1.0)$ \\
\hline Helmand & $32(0.9)$ & - \\
\hline Zabul & $28(0.8)$ & - \\
\hline Jowzjan & $25(0.7)$ & - \\
\hline Bamyan & $22(0.6)$ & - \\
\hline Samangan & $22(0.6)$ & - \\
\hline Farah & $20(0.6)$ & - \\
\hline Panjshir & $17(0.5)$ & - \\
\hline Kapisa & $14(0.4)$ & - \\
\hline Sar-e-Pul & $10(0.3)$ & - \\
\hline Daykundi & $7(0.2)$ & - \\
\hline Nimroz & $6(0.2)$ & - \\
\hline Badghis & $4(0.1)$ & - \\
\hline Ghor & $5(0.1)$ & - \\
\hline Uruzgan & $5(0.1)$ & - \\
\hline Nuristan & $2(0.1)$ & - \\
\hline Other (combined) & - & $15(3.2)$ \\
\hline Unknown & $673(19.3)$ & 80 (19.2) \\
\hline
\end{tabular}

Table A7. Distribution of study cohort by gender and province of origin.

\begin{tabular}{|l|c|c|c|c|}
\hline \multirow{3}{*}{ Province } & \multicolumn{3}{|c|}{ No. (\%) } \\
\cline { 2 - 5 } & \multicolumn{2}{|c|}{ Adults $(n=3,072)$} & \multicolumn{2}{c|}{ Paediatric $(n=417)$} \\
\cline { 2 - 5 } & $\begin{array}{c}\text { Male } \\
(n=1,801)\end{array}$ & $\begin{array}{c}\text { Female } \\
(n=1,271)\end{array}$ & $\begin{array}{c}\text { Male } \\
(n=294)\end{array}$ & $\begin{array}{c}\text { Female } \\
(n=123)\end{array}$ \\
\hline Kabul & $326(18.1)$ & $316(24.9)$ & $62(21.1)$ & $26(21.1)$ \\
\hline Nangarhar & $152(8.4)$ & $120(9.4)$ & $31(10.5)$ & $22(17.9)$ \\
\hline Balkh & $108(6.0)$ & $77(6.1)$ & $22(0.2)$ & $9(7.3)$ \\
\hline Ghazni & $101(5.6)$ & $71(5.6)$ & $12(7.5)$ & $2(1.6)$ \\
\hline
\end{tabular}


Table A7. Distribution of study cohort by gender and province of origin. (Continued)

\begin{tabular}{|c|c|c|c|c|}
\hline Herat & $94(5.2)$ & 79 (6.2) & $7(4.1)$ & $4(3.3)$ \\
\hline Khost & $77(4.3)$ & $35(2.8)$ & $14(2.4)$ & $10(8.1)$ \\
\hline Paktia & 75 (4.2) & $47(3.7)$ & $8(4.8)$ & $0(0.0)$ \\
\hline Kunduz & $48(2.7)$ & $29(2.3)$ & $11(3.7)$ & $6(4.9)$ \\
\hline Logar & $43(2.4)$ & $43(3.4)$ & $8(2.7)$ & $1(0.8)$ \\
\hline Laghman & $39(2.2)$ & $25(2.0)$ & $7(2.4)$ & $2(1.6)$ \\
\hline Maidan Wardak & $36(2.0)$ & $31(2.4)$ & $4(1.4)$ & $3(2.4)$ \\
\hline Baghlan & 35 (1.9) & $8(0.6)$ & $4(1.4)$ & $1(0.8)$ \\
\hline Faryab & 34 (1.9) & $9(0.7)$ & $3(1.0)$ & $1(0.8)$ \\
\hline Kunar & $26(1.4)$ & $13(1.0)$ & $6(2.0)$ & $5(4.1)$ \\
\hline Parwan & 25 (1.4) & $18(1.4)$ & $2(0.7)$ & $5(4.1)$ \\
\hline Badakhshan & $23(1.3)$ & $9(0.7)$ & $5(1.7)$ & $0(0.0)$ \\
\hline Paktika & $22(1.2)$ & $19(1.5)$ & $7(2.4)$ & $1(0.8)$ \\
\hline Takhar & $21(1.2)$ & $13(1.0)$ & $5(1.7)$ & $2(1.6)$ \\
\hline Kandahar & $20(1.1)$ & $8(0.6)$ & $4(1.4)$ & $0(0.0)$ \\
\hline Zabul & 19 (1.1) & $9(0.7)$ & $0(0.0)$ & $0(0.0)$ \\
\hline Jowzjan & $18(1.0)$ & $4(0.3)$ & $2(0.7)$ & $1(0.8)$ \\
\hline Helmand & $16(0.9)$ & 14 (1.1) & $1(0.3)$ & $1(0.8)$ \\
\hline Samangan & $13(0.6)$ & $8(0.6)$ & $1(0.3)$ & $0(0.2)$ \\
\hline Bamyan & $11(0.6)$ & $10(0.8)$ & $1(0.3)$ & $0(0.0)$ \\
\hline Panjshir & $11(0.6)$ & $5(0.4)$ & $1(0.3)$ & $0(0.0)$ \\
\hline Farah & $10(0.6)$ & $10(0.8)$ & $0(0.0)$ & $0(0.0)$ \\
\hline Kapisa & $7(0.4)$ & $6(0.5)$ & $1(0.3)$ & $0(0.0)$ \\
\hline Sar-e Pul & $6(0.3)$ & $3(0.2)$ & $1(0.3)$ & $0(0.0)$ \\
\hline Daykundi & $5(0.3)$ & $1(0.1)$ & $1(0.3)$ & $0(0.0)$ \\
\hline Ghor & $4(0.2)$ & $0(0.0)$ & $1(0.3)$ & $0(0.0)$ \\
\hline Badghis & $3(0.2)$ & $0(0.0)$ & $0(0.0)$ & $1(0.8)$ \\
\hline Nimruz & $3(0.2)$ & $2(0.2)$ & $1(0.3)$ & $0(0.0)$ \\
\hline Uruzgan & $3(0.2)$ & $1(0.1)$ & $0(0.0)$ & $0(0.0)$ \\
\hline Nuristan & $1(0.2)$ & $1(0.1)$ & $1(0.3)$ & $0(0.0)$ \\
\hline Unknown & $366(20.3)$ & 227 (17.9) & $60(20.4)$ & 20 (16.3) \\
\hline
\end{tabular}

Table A8. Distribution of study cohort by cancer stage and outcomes.

\begin{tabular}{|l|c|c|c|c|}
\hline \multirow{2}{*}{ Characteristic } & \multicolumn{4}{|c|}{ No. (\%) } \\
\cline { 2 - 5 } & \multicolumn{2}{|c|}{ Adults $(n=3,072)$} & \multicolumn{2}{c|}{ Paediatric $(n=417)$} \\
\cline { 2 - 5 } & $\begin{array}{c}\text { Male } \\
(n=1,801)\end{array}$ & $\begin{array}{c}\text { Female } \\
(n=1,271)\end{array}$ & $\begin{array}{c}\text { Male } \\
(n=294)\end{array}$ & $\begin{array}{c}\text { Female } \\
(n=123)\end{array}$ \\
\hline Cancer stage & $1(0.1)$ & $5(0.4)$ & $0(0.0)$ & $0(0.0)$ \\
\hline Stage 0 & $140(7.8)$ & $118(9.3)$ & $29(9.9)$ & $15(12.2)$ \\
\hline Stage I & $246(13.7)$ & $332(26.1)$ & $39(13.3)$ & $16(13.0)$ \\
\hline Stage II & & & & \\
\hline
\end{tabular}


Table A8. Distribution of study cohort by cancer stage and outcomes. (Continued)

\begin{tabular}{|l|c|c|c|c|}
\hline Stage III & $704(39.1)$ & $468(36.8)$ & $68(23.1)$ & $18(14.6)$ \\
\hline Stage IV & $428(23.8)$ & $179(14.1)$ & $53(18.0)$ & $24(19.5)$ \\
\hline Unknown/Not Applicable & $282(15.7)$ & $169(13.3)$ & $105(35.7)$ & $50(40.7)$ \\
\hline Patient outcome & \multicolumn{5}{|l|}{} \\
\hline Lost to follow-up & $1,029(57.1)$ & $628(49.4)$ & $125(42.5)$ & $55(44.7)$ \\
\hline Active follow-up & $483(26.8)$ & $452(35.6)$ & $85(28.9)$ & $38(30.9)$ \\
\hline Active treatment & $98(5.4)$ & $89(7.0)$ & $27(9.2)$ & $6(4.9)$ \\
\hline Discharged & $48(2.7)$ & $32(2.5)$ & $16(5.4)$ & $2(1.6)$ \\
\hline Died & $143(7.9)$ & $70(5.5)$ & $41(13.9)$ & $22(17.9)$ \\
\hline
\end{tabular}

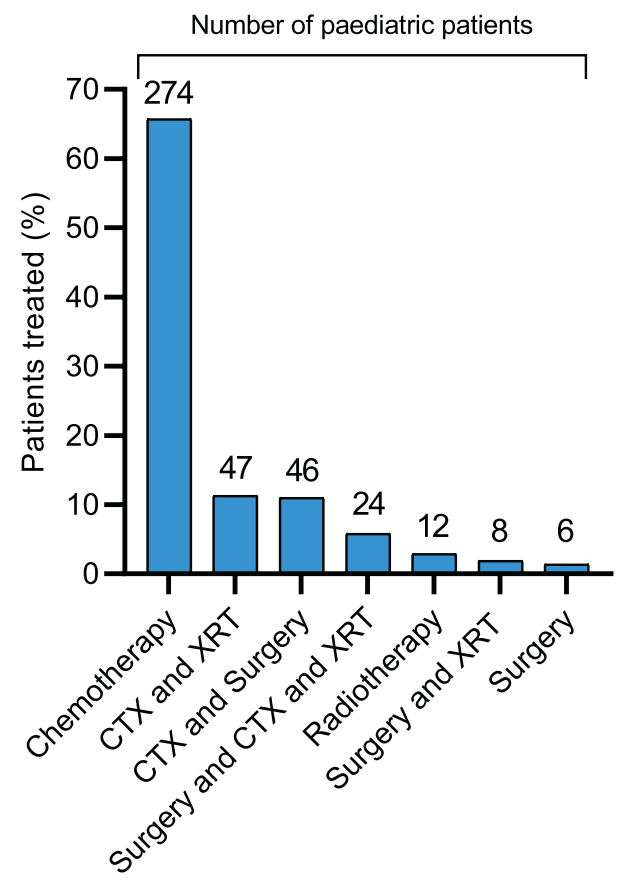

Figure A1. Distribution by treatment strategy in paediatric patients. 